\title{
The analysis of cognitive restructuring techniques effectiveness to reduce the online game addiction
}

\author{
Nuzuli Rahmatillah ${ }^{1^{*}}$, Farida Agus Setiawati ${ }^{2}$ \\ 1,2 Universitas Negeri Yogyakarta, Yogyakarta, Indonesia \\ ${ }^{*}$ Corresponding author, e-mail: nuzulirahmatillah05@gmail.com
}

\begin{abstract}
In schools there are still many students who experience academic disorders such as lazy learning, often neglecting assignments, often skipping school, this is because one of them is because students are addicted to playing online games. This study aims to analyze the effectiveness of cognitive behavioral therapy (CBT) counseling with cognitive restructuring techniques to reduce online game addiction behavior of students. This research is a quantitative study with a quasi-experimental method. The population in this study were students who were addicted to online games. Sampling using a purposive sampling technique, so that the subjects in the experimental group were 8 students and the control group was 8 students. Data collection was done using online game addiction scale that has been tested for validity and reliability. Data analysis using score gain testing. The results showed that CBT cognitive restructuring techniques were effective in reducing online game addiction on students. The CBT cognitive restructuring techniques are effective in reducing online game addiction on students.
\end{abstract}

Keywords: Online game addiction, CBT cognitive restructuring counseling techniques.

How to Cite: Rahmatillah, N., \& Setiawati, F. A. (2020). The analysis of cognitive restructuring techniques effectiveness to reduce the online game addiction. International Journal of Research in Counseling and Education 4(2), 104-109. doi:https://doi.org/10.24036/00263za0002

\section{Introduction}

Play is an important element for children's physical, emotional, mental, intellectual, creativity, and social development (Soetjiningsih, 1998). School age children are group age or often referred to as age adjustment (Church \& Stone in Hurlock, 2008). During the development of school-age children, the most popular games are competitive games (Hurlock, 2008). School-age children develop the ability to play games with regulations, (Desmita, 2008). Nowadays, the development of internet technology is warm, online game is no less blooming, its development is very fast (Harwood \& Eaves, 2020; Magistretti, Dell'Era, \& Verganti, 2020). Online games are electronic and visual based games (Rini, 2011). Online games have a very big difference with other games that gamers can not only play with the person next to them but can also play with several other players in other locations, even up to players in other parts of the world (Young, 2007). Children are considered to be more frequent and vulnerable to the use of online gaming than adults (Griffiths \& Wood, 2000 in Lemmens, 2009).

Online game addiction is characterized by the extent to which gamers play games excessively which can negatively affect the gamers (Weinstein, 2010). Online game addiction criteria as well as internet addiction include excessive use, withdrawal symptoms, tolerance and negative effects (Young, 2011). This is because these four aspects better describe online gaming addictions, especially in students. Based on interviews and observations with Guidance and Counseling Teachers at SMK Negeri 2 Yogyakarta, the phenomenon of online game addiction is found at SMK Negeri 2 Yogyakarta, especially in class XI students. The majority of SMK Negeri 2 Yogyakarta students have gadgets such as mobile phones, i-pad, tabs and laptops that can access online gaming sites. In addition, the available wifi facilities at school also make it easier for students to be able to use the internet while in school. The habit of playing online games at school is done by students during recess or when there are no teachers in the class. Aside from school, students also play online games in internet cafes and in their homes using personal computers (PCs). There are even some students who deliberately did not enterschool (truant) just to play online games in internet cafes or games center. The activity of playing online games in class often creates teachers especially subject teachers feel uneasy because of the lessons being 
deliveredoften can not be understood by students in class. Apart from that, choresthe schools they provide are often not done by them. Besides activity on class, the low academic value obtained by students each time a testand remedial always cause anxiety for the subject teachersespecially. Learners' awareness of their duties and responsibilities asstudents they often ignore.

Researchers are interested in taking samples of school-age children because children are considered to be more frequent and vulnerable to the use of online games than adults (Griffiths \& Wood, 2000 in Lemmens, 2009; Derevensky, Hayman, \& Lynette Gilbeau, 2019; Wartberg, Kriston, \& Thomasius, 2020). Therefore, the authors are interested in conducting research on the effectiveness of cognitive restructuring techniques for the addiction of playing online games in school-age children at SMK Negeri 2 Yogyakarta. The purpose of this study was to determine the effectiveness of cognitive restructuring techniques to reduce online game addiction in school-aged children at SMK Negeri 2 Yogyakarta. The purpose of this research is to provide input for educators to reduce and prevent addiction from playing online games and the results of this study can be used as a basis for further research (Aristoteles, Rini, \& Poddar, 2020). online games or ignoring basic needs, withdrawal symptoms if not using the internet which is marked by feeling so scared, anxious and depressed, tolerance is marked by the desire for someone to get access tools such as gadgets to get a better internet network, someone's keiginess in adding network applications socially attractive, and cannot stop not playing online games, the negative impact that is marked by arguing or talking hoax, poor performance, social isolation, and fatigue (Young, 2011).

\section{Method}

This type of research used in this study is quantitative. The variables in this study are addiction to play online games, namely excessive use, withdrawal symptoms, tolerance and negative impacts (Young, 2011). The population in this study were students of SMK Negeri 2 Yogyakarta class XI with a total of 110 students and this study used sampling in the form of purposive sampling, then obtained a sample of 16 students for the control group and the experimental group. The criterion is students who have addictions to online games in very high and high category, which are given counseling treatment for cognitive restructuring techniques, to get the subject the researchers conducted a pretest by providing an online game addiction scale that has been validated by experts. Data collection techniques in this study were to using online game addiction scales and after giving treatments researchers gave the posttest in the same scale as the pretest. Validity was obtained through item testing by experts, and reliability was obtained through Cronbach's Alpha testing, which resulted in a score of 0.91. Determination of the subject is taken based on the results of scale measurements that are classified in the category very high/high. The following is a table of online games addiction categories:

Table 1. Online Game Addiction Level Category

\begin{tabular}{ccc}
\hline Addiction category & \multicolumn{2}{c}{ Interpretation } \\
\hline $\mathrm{M}+1,50 \mathrm{~s}<\mathrm{X}$ Theta & $60,80<\mathrm{X}$ Theta & Very high \\
$\mathrm{M}+0,50 \mathrm{~s}<\mathrm{X}<(\mathrm{M}+1,50 \mathrm{~s})$ & $49,56<\mathrm{X} \leq 60,80$ & High \\
$\mathrm{M}-0,50 \mathrm{~s}<\mathrm{X}<(\mathrm{M}+0,50 \mathrm{~s})$ & $43,78<\mathrm{X} \leq 49,56$ & Medium \\
$\mathrm{M}-1,50 \mathrm{~s}<\mathrm{X}<(\mathrm{M}-0,50 \mathrm{~s})$ & $38,10<\mathrm{X} \leq 43,78$ & Low \\
Theta $\mathrm{X}<(\mathrm{M}-1,50 \mathrm{~s})$ & Theta $\mathrm{X} \leq 38,10$ & Very low \\
\hline
\end{tabular}

Furthermore, this study uses a gain score test which is to find out the differences of the two groups between the experimental group and the control group after and before treatment. To find these results using the help of the SPSS application (statistical package for social science).

\section{Results and Discussion}

The online game addiction scale that was collected was then analyzed and obtained 44 students with high online game addiction scores and 3 students had very high online game addiction scores, 29 students had moderate scores, 15 students got low scores, and 19 students had score of online game addiction is very low in SMK Negeri 2 class XI Yogyakarta. Implementation of treatments must be based on the principle of willingness, for that based on the results of initial measurements and willingness to counsel cognitive restructuring techniques, then after analyzing, researchers contact students who have addictions to online games that are very high and high, but in the end only 16 students are ready and willing to attend group counseling treatment techniques cognitive restructuring. Then divided into 2 groups, 8 students will be given treatment and 8 students as the control group. Here are the results of preetest and posttest online game addiction given to the group given treatment in the Table 2. 
Table 2. The results of preetest and posttest online game addiction given to the treatment group

\begin{tabular}{cccc}
\hline Pretest Results & Categories & $\begin{array}{c}\text { Posttest } \\
\text { Results }\end{array}$ & Categories \\
\hline 92 & Very High & 61 & Very High \\
61 & Very High & 41 & Low \\
56 & High & 40 & Low \\
53 & High & 39 & Low \\
59 & High & 41 & Low \\
55 & High & 46 & Medium \\
58 & High & 39 & Low \\
50 & High & 36 & Very Low \\
\hline
\end{tabular}

Based on the table above the results of the pretest and posttest assessment it is known that counselee 1 has experienced a significant decrease, that is the result before being treated 92 to 61 , it's just that it is still in a very high category compared to other counselees, counselee 2 before being treated 61 to 41 , counselee 3 has a score of 55 decreased to 40 , while the decrease that occurred in counselee 4 decreased before being given treatment 53 to 39, counselee 5 before being given treatment 59 decreased 41 , counselee 6 before being given treatment 55 decreased to 46 , and counselee 7 before getting 58 decreased treatment to 39 , then the last counselee also decreased after getting treatment.

Descriptions of the results of preetest and posttest addiction to online games The control group is a subject that is not subject to treatment, the following preetest and posttest results given to the control group are presented in tabular form:

Table 3. The result of preetest and posttest results given to the control group

\begin{tabular}{cccc}
\hline Pretest Results & Categories & $\begin{array}{c}\text { Posttest } \\
\text { Results }\end{array}$ & Categories \\
\hline 66 & Very High & 63 & Very High \\
55 & High & 55 & High \\
53 & High & 56 & High \\
55 & High & 58 & High \\
53 & High & 56 & High \\
53 & High & 57 & High \\
54 & High & 56 & High \\
54 & High & 57 & High \\
\hline
\end{tabular}

Based on the table above, the results of the preetest and posttest data assessment of online game addiction in the control group showed no significant changes that occurred between the posttest and posttest scores. The first counselee 1 has decreased from the results of preetest and posttest with a total score of 66 to 63 . This did not occur in the second counselee 2 that did not experience a decrease in the number of scores from 55 to 55 , while counselee 3 did not experience a decrease in the total score from 53 to 56 , the counselee 4 did not decrease the number of scores from 55 to 58 , counselee 5 also did not decrease ie from the total score of 53 to 56, counselee 6 also did not decrease from the total score of 53 to 57, then counselee 7 also did not experience a decrease from the number of scores obtained 54 to 56 , and the last counselee 8 did not experience a decrease in the number of initial scores obtained 54 to 57 . The acquisition can be seen from every aspect there was no decline.

Table 4. , The gain score of the online game addiction of the experimental group and the control group

\begin{tabular}{cccc}
\hline Group & Post-Test & Pre-test & Gain Score \\
\hline Experiment & 42.88 & 63.13 & -20.25 \\
Control & 57.25 & 57.13 & 0.12 \\
\hline
\end{tabular}

Based on the above table, the gain score of the online game addiction of the experimental group and the control group shows that the mean post-test value of the experimental group is 42.88 , the mean pretest value of the experimental group is 63.13 with the gain score of -20.25 , while the mean post-test value of the control group amounted to 57.25, and the mean pretest value in the control group was 57.13 with a gain score of 0.12 , this proves that the decrease in online game addiction in the experimental group was more than in the control 
group. It can be concluded that there is a difference in the decrease of online game addiction between the experimental group and the control group after the treatment using CBT cognitive restructuring techniques shows that the decrease in online game addiction in students.

After being given counseling treatment to the experimental group with CBT restructuring techniques, the researcher then shared the scale of online game addiction which was the same as the scale given before the treatment was given as a post-test to the experimental and control groups. Changes in scores on the pre-test and post-test results are indicators of success with a significant difference in the hypothesis test results of research data. Based on the results of the analysis of hypothesis testing in the pre-test and post-test of the experimental group and the control group there are significant differences in changes in online game addiction. Research subjects in the experimental group experienced a significant decrease while the control group did not have a significant difference. This means that the hypothesis in this study was accepted. So it can be concluded that cognitive behavioral therapy cognitive cognitive restructuring technique counseling is effective in reducing online game addiction in class XI students of SMK Negeri 2 Yogyakarta.

CBT treatment of cognitive restructuring techniques is effective because this treatment has stages that are used (Espil \& Houghton, 2018; Karekla et al., 2020; Kerwin \& Bopp, 2014), namely 1) the rational stage in which the role of a counselor explains the purpose of counseling and procedures that must be carried out by the counselee, 2) identification is the stage where a counselor's role in doing identification of counselee thought in looking for distortions counselee thought, 3) introduction and practice in overcoming wrong thoughts, 4) counselor provides a way to be able to divert the mind, blame yourself by providing help on how to overcome their own thoughts, 5) counselor provides an explanation of how do a positive self-declaration technique then the counselee practices it, 6 ) the counselor assigns homework.

CBT with cognitive restructuring technique is effective against reducing online game addiction because cognitive restructuring technique is a technique that helps change irrational thinking in a more positive direction or towards irrational so that it can change someone's behavior (Christie et al., 2019; Dieris-Hirche et al., 2020; Kim, Han, Lee, \& Renshaw, 2012; Kolstee et al., 2020; Muroff \& Robinson, 2020; Taquet, Hautekeete, \& Gorgeu, 2014). This is in line with the opinion of Aaron T. Beck (2011) that the cognitive behavior therapy approach is a counseling approach designed to solve problems experienced by the counselee by providing several techniques, one of which is cognitive restructuring. According to Corey (2013) cognitive restructuring technique is one of the techniques used in the cognitive behavioral therapy approach, this technique focuses more on modifying irrational thinking and directing rational thoughts and helping counselees in finding selfdefeating thoughts and looking for rational alternatives so that adolescents can learn to deal with situations that cause anxiety.

The purpose of cognitive restructuring techniques According to Corey (2013) is to help build the mindset of the counselee who is more in line with what is expected and is positive or rational. This is in line with what was stated by Deacon (2011) who said that the restructuring technique was built in order to form an adaptive or appropriate mindset that is more positive in nature. In this case cognitive restructuring techniques in helping counselees to be able to learn to think differently that originally had wrong thoughts then changed or replaced them with more rational and realistic thinking. The results of this research hypothesis are also in line with research conducted by Hardiyansyah Masya (2013) that cognitive behavioral counseling is effective for dealing with internet addiction disorders. Other studies also conducted by Andre Julius (2016) prove that cognitive behavioral counseling is effective in reducing Cybersex Addiction. Siti Fatimah (2015), has also proven that cognitive behavioral therapy is effective in reducing academic stress in students of Class XI Pharmacy at AlWafa Vocational School Bandung.

Students who have a very high and high level of online game addiction have excessive pleasure and consider themselves to be okay so that excessive expectations arise. This happens because students assume by playing online games they will feel better without knowing the effects of addiction to playing online games. Lack of information about the effects of online game addiction received is a threat to him, so he will be overwhelmed with anxiety and irrational thoughts. Based on this the researchers felt the need to improve negative self concepts to be positive.

Addiction to online games is part of a form of addiction related to the joy that arises in the mind of someone so that there is no self-control in a person. According to Nimnas (2017), the same opinion is that addiction occurs because of the feeling of pleasure in the brain. Whatever the activity, whether it's sex, psychoactive drugs, abundant wealth, or food that tastes good, will be interpreted with the same thing in the brain. Someone who is addicted to online games can be seen from how much time is spent playing online games, this is in agreement expressed Weinstein (2010) addiction to online games is characterized by the extent to which teens play online games excessively which can have a negative influence on these players. In this study, the concept of online game addiction is divided into four aspects, namely overuse, withdrawal symptoms, tolerance and 
negative impacts Young (2011). The following will discuss the effects of CBT counseling on cognitive restructuring techniques to reduce online game addiction in class XI students of SMK Negeri 2 Yogyakarta.

he aspect of excessive use is part of the first online gaming addiction felt by individuals. This excessive use is related to the irrational thoughts of individuals towards online games that think more so that it affects the task of their development as a student. This excessive use will affect the mind and addictive behaviors arise. The use of CBT group cognitive cognitive restructuring techniques can help modify irrational thinking and direct rational thoughts and help counselees in finding self-defeating thoughts and looking for rational alternatives so that counselees can learn to deal with situations which are the cause of online game addiction. According to Corey (2013) the advantage of cognitive restructuring techniques is that cognitive restructuring techniques are central techniques in cognitive behavioral counseling that teaches individuals how to improve themselves by replacing irrational beliefs with rational beliefs. CBT group counseling with cognitive restructuring techniques seeks to teach individuals to improve by replacing irrational beliefs with the rational beliefs of the individual itself so that better behaviors arise, so when someone's problem is overused, then the counseling process helps individuals to provide awareness of the use overuse online games using CBT cognitive restructuring techniques that will help explore desires and beliefs, things they might be able to do, opportunities for self-evaluation, and design plans for improvement.

CBT counseling restructuring technique seeks to make individuals able to regulate the strength within the counselee by providing coping thought, so when someone's problem with withdrawal symptoms, the counseling process helps individuals to provide strength and awareness of withdrawal symptoms using counselee cognitive restructuring techniques can design a plan for improvement (Taquet, Romo, Cottencin, Ortiz, \& Hautekeete, 2017). CBT counseling with cognitive restructuring techniques can reduce online game addiction in the aspect of tolerance. desire someone to get access tools such as gadgets to get a better internet network, someone's dignity in adding interesting social networking applications, and can not stop not playing online games (Mastroleo et al., 2020). This concerns the extent to which someone can not stop when playing online games. Then the CBT counseling process of cognitive restructuring techniques uses a way for a person to resist his desires when playing online games by using coping thoughts and replacing more positive activities. On the issue of addiction to online games on the negative impact aspects, which are characterized by arguing or talking hoax, poor achievement, social isolation, and fatigue (Rodda et al., 2019). CBT counseling for cognitive restructuring techniques tries to debate the more positive thoughts of the positive counselee and gives advice from the counselor and is also obtained from other group members.

Based on the calculation results after being given treatment using CBT counseling cognitive restructuring techniques to reduce online game addiction, students experience a decrease in online game addiction from before the treatment was given. This can be seen from the results of the behaviors shown such as students starting to change activities more positively, being optimistic, thinking more irrational.

\section{Conclusion}

Based on data analysis and discussion, the results of the study can be concluded as a CBT approach to cognitive restructuring techniques proven to be effective in reducing students' online game addiction, in providing cognitive restructuring techniques students can learn and experience new, giving restructuring techniques in CBT can also provide solutions to overcome addictions online game.

\section{References}

Aristoteles, Rini, P. S., \& Poddar, S. (2020). The correlation between frequency of playing online games and teen communication on nursing students in STIKes Muhammadiyah Palembang. Enfermería Clínica, 30, 1-5. https://doi.org/https://doi.org/10.1016/j.enfcli.2019.11.014

Christie, G. I., Shepherd, M., Merry, S. N., Hopkins, S., Knightly, S., \& Stasiak, K. (2019). Gamifying CBT to deliver emotional health treatment to young people on smartphones. Internet Interventions, 18, 100286. https://doi.org/https://doi.org/10.1016/j.invent.2019.100286

Derevensky, J. L., Hayman, V., \& Lynette Gilbeau. (2019). Behavioral Addictions: Excessive Gambling, Gaming, Internet, and Smartphone Use Among Children and Adolescents. Pediatric Clinics of North America, 666), 1163-1182. https://doi.org/https://doi.org/10.1016/j.pcl.2019.08.008

Dieris-Hirche, J., Pape, M., te Wildt, B. T., Kehyayan, A., Esch, M., Aicha, S., ... Bottel, L. (2020). Problematic gaming behavior and the personality traits of video gamers: A cross-sectional survey. Computers in Human Behavior, 106, 106272. https://doi.org/https://doi.org/10.1016/j.chb.2020.106272

Espil, F. M., \& Houghton, D. C. (2018). Chapter 5 - Cognitive Restructuring About Tics(J. F. McGuire, T. K. Murphy, J. Piacentini, \& E. A. B. T.-T. C. G. to T. and M. of Y. with T. S. and T. D. Storch, eds.). https://doi.org/https://doi.org/10.1016/B978-0-12-811980-8.00005-4 
Harwood, S., \& Eaves, S. (2020). Conceptualising technology, its development and future: The six genres of technology. Technological Forecasting and Social Change, 160, 120174. https://doi.org/https://doi.org/10.1016/j.techfore.2020.120174

Karekla, M., Georgiou, N., Panayiotou, G., Sandoz, E. K., Kurz, A. S., \& Constantinou, M. (2020). Cognitive Restructuring vs. Defusion: Impact on craving, healthy and unhealthy food intake. Eating Behaviors, 37, 101385. https://doi.org/https://doi.org/10.1016/j.eatbeh.2020.101385

Kerwin, S., \& Bopp, T. (2014). Exploring cognitive restructuring: A multi-foci leadership perspective. Sport Management Review, 173), 277-291. https://doi.org/https://doi.org/10.1016/j.smr.2013.11.005

Kim, S. M., Han, D. H., Lee, Y. S., \& Renshaw, P. F. (2012). Combined cognitive behavioral therapy and bupropion for the treatment of problematic on-line game play in adolescents with major depressive disorder. $\begin{array}{lllll}\text { Computers in } & \text { Human }\end{array}$ https://doi.org/https://doi.org/10.1016/j.chb.2012.05.015

Kolstee, J., Holt, M., Jin, J., Hammoud, M. A., Degenhardt, L., Maher, L., ... Prestage, G. (2020). Characteristics of gay and bisexual men who rarely use HIV risk reduction strategies during condomless anal intercourse: Results from the FLUX national online cohort study. PLOS ONE, 15(6). https://doi.org/10.1371/journal.pone.0233922

Magistretti, S., Dell'Era, C., \& Verganti, R. (2020). Searching for the right application: A technology development review and research agenda. Technological Forecasting and Social Change, 151, 119879. https://doi.org/https://doi.org/10.1016/j.techfore.2019.119879

Mastroleo, N. R., Humm, L., Williams, C. M., Kiluk, B. D., Hoadley, A., \& Magill, M. (2020). Initial testing of a computer-based simulation training module to support clinicians' acquisition of CBT skills for substance use disorder treatment. Journal of Substance Abuse Treatment, 114, 108014. https://doi.org/https://doi.org/10.1016/j.jsat.2020.108014

Muroff, J., \& Robinson, W. (2020). Tools of Engagement: Practical Considerations for Utilizing Technology-Based Tools in CBT Practice. Cognitive and Behavioral Practice. https://doi.org/https://doi.org/10.1016/j.cbpra.2020.01.004

Rodda, S. N., Merkouris, S., Lavis, T., Smith, D., Lubman, D. I., Austin, D., ... Dowling, N. A. (2019). The therapist experience of internet delivered CBT for problem gambling: Service integration considerations. Internet Interventions, 18, 100264. https://doi.org/https://doi.org/10.1016/j.invent.2019.100264

Taquet, P., Hautekeete, M., \& Gorgeu, É. (2014). Cognitive, emotional, and behavioral determinants involved in the use of video games: Towards a better understanding of excessive gaming for CBT interventions. Journal de Thérapie Comportementale et Cognitive, 24(2), 53-62. https://doi.org/https://doi.org/10.1016/j.jtcc.2014.02.001

Taquet, P., Romo, L., Cottencin, O., Ortiz, D., \& Hautekeete, M. (2017). Video Game Addiction: Cognitive, emotional, and behavioral determinants for CBT treatment. Journal de Thérapie Comportementale et Cognitive, 273), 118-128. https://doi.org/https://doi.org/10.1016/j.jtcc.2017.06.005

Wartberg, L., Kriston, L., \& Thomasius, R. (2020). Internet gaming disorder and problematic social media use in a representative sample of German adolescents: Prevalence estimates, comorbid depressive symptoms and related psychosocial aspects. Computers in Human Behavior, 103, 31-36. https://doi.org/https://doi.org/10.1016/j.chb.2019.09.014

Weinstein, A. M. (2010). Computer and video game addiction - a comparison between game users and non game users. The American Journal of Drug and Alcohol Abuse, 36, 268-276. doi: https://doi.org/10.3109/00952990.2010.491879

Weinstein, A. M. (2010). Computer and video game addiction - a comparison between game users and non game users. The American Journal of Drug and Alcohol Abuse, 36, 268-276. doi: 10.3109/00952990.2010.491879 (diakses Oktober 2011).

Young, K. S. (1999). Internet addiction: symptoms, evaluation, and treatment. Innovations in Clinical Practice (Volume 17) by L. VandeCreek \& T. L. Jackson (Eds.), Sarasota, FL: Professional Resource Press.

Young, K. S., \& Abreu, C. N. D. (2011). Internet Addiction: A Handbook and Guide to Evaluation and Treatment. Canada: John Willey \& Sons, Inc. 